\title{
CHANGING THE PUBLIC DRUNKENNESS LAWS: THE IMPACT OF DECRIMINALIZATION
}

\author{
DAVID E. AARONSON \\ C. THOMAS DIENES \\ MICHAEL C. MUSHENO
}

\begin{abstract}
Laws that decriminalize public drunkenness continue to use the police as the major intake agent for public inebriates under the "new" public health model of detoxification and treatment. Assuming that decriminalization introduces many disincentives to police intervention using legally sanctioned procedures, we hypothesize that it will be followed by a statistically significant decline in the number of public inebriates formally handled by the police in the manner designated by the "law in the books." Using an "interrupted time-series quasiexperiment" based on a "stratified multiple-group single-I design," we confirm this hypothesis for Washington, D.C., and Minneapolis, Minnesota. However, through intensive "microanalysis" of these two jurisdictions, we show that Minneapolis, in responding to strong business pressure, developed several alternative means of keeping the streets clear of transient public inebriates while Washington, D.C., treated decriminalization as an opportunity to shift police priorities and relied on informal "safe zones" to handle the inebriate population.
\end{abstract}

\section{INTRODUCTION}

Decriminalization as an alternative strategy for handling public drunkenness took hold in the 1960s and early 1970s (Kittrie, 1971; Morris and Hawkins, 1969; Schur, 1965; Schur and Bedau, 1974). ${ }^{1}$ The regional and national forces that coalesced around this issue as reform-oriented policy subsystems (Freeman, 1965; Fritschler, 1969) focused on both the illegitimacy and impracticability of the attempts by the system of criminal justice to handle this social and public health problem (Nimmer, 1971:102-5). In states where decriminalization eventually oc-

This article is based on a larger study of the decriminalization of public drunkenness funded by LEAA-NILECJ, Grant No. 74NI-99-0055. Those parts of the study that deal with police discretion as an explanation for the impact of decriminalization, and with the analysis of alternative policies for dealing with the pickup and delivery of public inebriates, are contained in our final report (Aaronson et al., 1977b) and in another journal (Aaronson et al., 1977a, 1978). We gratefully acknowledge the many persons who commented on earlier drafts and criticized the methodological development of this paper: Richard Abel, Egon Bittner, Bruce Bowen, Gene Glass, Dorothy Guyot, Michael Hindus, Laura Irwin, James Levine, Dennis Palumbo, David Perry, H. Laurence Ross, Peter Rossi, Charles Ruttenberg, and George Silberman.

1. By the end of 1976 , some 24 states had enacted the National Conference of Commissioners on Uniform State Laws' Uniform Alcoholism and Intoxication Treatment Act (1971) or essentially similar legislation. Well over half the states have decriminalized public drunkenness. Many others have diversionary strategies in cities where criminal statutes remain in effect. See Grad et al. (1971); U.S. Department of H.E.W. (1971); Nimmer (1971). 
curred either through legislation or judicial action, reformers paid little attention to the potential reaction of the police. They simply assumed that the police would continue to serve as intake agents for public inebriates under the "new" public health model of detoxification and treatment.

This article empirically evaluates the impact of decriminalization on police performance in Washington, D.C., and Minneapolis, Minnesota. We question the facile assumption that the police will routinely perform this new task. Specifically, we hypothesize that decriminalization will be followed by a statistically significant decline in the number of public inebriates formally handled by the police in the manner designated by the "law in the books."

The conceptual basis for this hypothesis is derived from the literature on organization theory and from studies of police behavior. ${ }^{2}$ For example, it can be argued that as a result of the removal of the criminal sanction, the intake of public inebriates will no longer be viewed by patrol officers or the command structure as a proper or important task (Wilson, 1971:49). Decriminalization also eliminates critical organizational incentives that motivate patrol officers to carry out this often messy and time-consuming job. ${ }^{3}$ Indeed, the very fact that the officer is no longer being asked to enforce the criminal law provides a source of dissonance. Further, police intake of inebriates under a public health mandate requires the cooperation of two different public service bureaucracies that diverge in both organization and values. Such a fragmented authority structure is a potential impediment to goal achievement.

Thus, given the broad discretionary powers available to implementing agencies and their respective street-level bureaucrats (Davis, 1975), we would argue that any newly formulated task that runs counter to the organizational and individual selfinterests of a critical public service bureaucracy is very unlikely to achieve full implementation unless these new mandates are supported by their own incentives at both the

2. As indicated in the authors' note, police discretion as an explanation for the police behavior discussed herein is not treated extensively in this article. There is a voluminous literature on police discretion by political scientists, sociologists, and legal and criminal justice scholars, e.g., Davis (1975); Goldstein (1960); La Fave (1965); Skolnick (1967); Wilson, J.Q. (1968). Studies of police discretion that are particularly relevant to the enforcement of public drunkenness include Gammage et al. (1972); Bittner (1967); Nimmer (1971); Pittman and Gordon (1967); Rubington (1970).

3. For example, departments have often given the same credit for such arrests that they award for other misdemeanors and for traffic citations. Jerry V. Wilson, the former Police Chief of Washington, D.C., has noted the importance of this incentive (1975). 
administrative and street levels (Musheno et al., 1976). In short, decriminalization introduces numerous disincentives to formal police intervention using approved means (Aaronson et al., 1977a, 1978).

Our research design reflects the growing body of literature that merges the common threads of empirical impact analysis and public policy analysis (Dye, 1972:291-96). This "policy impact study" empirically evaluates the impact of state judicial and legislative mandates on agency responses (Campbell and Ross, 1968; Glass et al., 1971; Ross, 1975; Zimring, 1975). Thus we seek to contribute to correcting the "upper court bias" associated with public law research (Dolbeare, 1967) and to developing the literature of policy analysis that empirically assesses the way public agencies interpret the law (Medalie et al., 1968; Milner, 1970; Ostrom, 1973).

\section{DECRIMINALIZATION: TRACING THE PHASES AND SOURCES OF LEGAL REFORM}

One can divide decriminalization proposals into those that are accompanied by treatment alternatives and those that are not (Aaronson and Sweeney, 1975; Aaronson et al., 1977c; Titus, 1973). Although those proposals without a treatment scheme may include regulatory guidelines (e.g., gambling and obscenity laws), they are primarily intended to permit a previously prohibited activity by eliminating the criminal sanction. Alternatively, proposals linked to treatment alternatives are usually designed to provide a more effective means of regulating an activity. The movement to decriminalize public drunkenness is an example of this latter category.

Washington and Minneapolis have experienced three legal phases in the handling of public inebriates: a criminal phase, a transitional phase, and a public health phase. In both jurisdictions, the transitional phase was marked by judicial decisions that overturned convictions of chronic skid-row inebriates for drunkenness. Decriminalization and the emergence of the public health phase were the product of legislation that required the establishment of new institutions for servicing the public inebriate population.

\section{A. Washington, D.C.}

Prior to Easter v. District of Columbia (361 F.2d 50, D.C. Cir., 1966), the public inebriate in Washington was handled within the criminal process. The usual procedure involved a police arrest for alleged violation of D.C. Code $\S 25-128$, which 
made it a crime to be "drunk or intoxicated in any street, alley, park, or parking in any vehicle in or upon the same or in any place to which the public is invited or at any public gathering, and no person anywhere shall be drunk or intoxicated and disturb the peace of any person." Violations of this statute were punishable by a fine of not more than $\$ 100$ and/or imprisonment for not more than 90 days.

The legal challenge to this public intoxication statute in the Easter case relied, in part, on the fundamental principle of criminal responsibility that criminal sanctions may be applied only to voluntary action (see Robinson v. California, 390 U.S. $669,1962)$. In Easter, the United States Court of Appeals for the District of Columbia held that the defendant could not be convicted of public intoxication because, as a chronic alcoholic, he had lost the power of self-control with respect to the use of alcoholic beverages and thus, under a local statute as well as under traditional legal principles, he could not be convicted for his involuntary intoxication. ${ }^{4}$ However, there were factors that substantially limited the impact of this ruling. ${ }^{5}$ It applied only to the "chronic alcoholic." Public intoxication remained a

4. The Court in Easter cited D.C. Code $\$ 24-501$ et seq. authorizing courts in the District of Columbia to take notice of the fact that a chronic alcoholic is a sick person in need of treatment and authorizing the court to order such treatment. Further, a chronic alcoholic was defined in the code as a person who has lost "self-control" because of the use of alcohol. Considering these provisions in the context of the act as a whole, the court concluded that Congress had intended that criminality should not attach where responsibility is lacking, i.e., chronic alcoholism (361 F.2d 51-53).

The Court also relied heavily on Driver v. Hinnant 356 F.2d 761 (4th Cir. 1966), concluding that a chronic alcoholic cannot have the mens rea necessary for criminal responsibility. It was also suggested that criminal punishment under such circumstances might offend the constitutional prescription against cruel and unusual punishment (361 F.2d 53-55).

5. The potential of Easter as a catalyst for national reform of the drunkenness laws was subsequently blunted by the Supreme Court's decision in Powell v. Texas $(392$ U.S. 514, 1968), which rejected the contention that criminal prosecution of the chronic public inebriate constitutes cruel and unusual punishment in violation of the Eighth Amendment to the United States Constitution. The recent Supreme Court decision in O'Connor v. Donaldson (422 U.S. 563, 1975), dealing with a "right to treatment," might appear to offer a new avenue for attacking incarceration of the inebriate, at least where the confinement is involuntary. The Court there held that Fourteenth Amendment Due Process is violated where a state involuntarily confines a mentally ill person who is not dangerous to self or to others, if no treatment is provided.

However, involuntary confinement of the public inebriate in criminal and decriminalized jurisdictions is often premised on a finding of dangerousness (see Grad et al., 1971) thereby raising a question left open by the Donaldson case-can a dangerous person be involuntarily confined where no treatment is afforded? In decriminalized jurisdictions (and many jurisdictions that were formally criminal), confinement is often limited to a short "sobering up" period. In the decrimininalized jurisdiction, treatment is usually provided if confinement continues and confinement is usually based on some consent. Of course, what constitutes "consent" for an intoxicated person is itself a difficult legal question. 
crime but there was increased uncertainty whether an arrest would result in a conviction. Further, the lack of any systematic therapy for the chronic inebriate resulted in a "revolving door" that was even more of a sham than the previous criminal process. The result for the police was general confusion (Wilson, 1975).

On August 1, 1968, the District of Columbia Alcoholic Rehabilitation Act (P.L. 90-452, 82 Stat. 618, 1968), went into effect, a direct result of Easter and its chaotic aftermath. The Act directs all public officials in the District of Columbia to "take cognizance of the fact that public intoxication shall be handled as a public health problem rather than as a criminal offense" (Alcoholic Rehabilitation Act D.C. Code Annot. § 24-521 et seq.). Nevertheless, the statute retains the assumption that simple public intoxication is sufficient ground for public intervention regardless of the wishes of the intoxicated individual. The police are retained as the legal instument for removing intoxicated persons from the streets, but they pick up "patients" under a public health statute that reads:

Except as provided in subsection (b) of this section, any person who is intoxicated in public: (1) may be taken or sent to his home or to a public or private health facility; (2) if not taken or sent to his home or such facility under paragraph one shall be taken to a detoxification center. [D.C. Code 24-524]

The Metropolitan Police Department promulgated regulations recognizing intoxication (General Order No. 8, 1968) and dividing intoxicated persons into three classes: (1) those not endangering the safety of themselves or other persons or property (D.C. Code $\S 25-218$ ), (2) those who endanger the safety of themselves or other persons or property (D.C. Code $\S 25-218$ ), and (3) those charged with criminal offenses other than those specified in D.C. Code $\S 25-218$ (General Order No. 11, 1968).

The police department remains the primary intake agent for all three classes. Persons picked up under the first category are taken home or to the Detox (the Detoxification Center) and no arrest notation results (other forms are substituted). Public inebriates who do endanger the safety of themselves or others (a criminal offense), are arrested and taken to the Detox, where the medical officer is given a detainer authorizing their transfer to jail when detoxified. Although those in the third category should also be taken to Detox, it lacks adequate security; therefore any person who is considered a potential escapee is presently treated like any other criminal.

Easter provided the initial catalyst for change in the legal status of public drunkenness in the District of Columbia. The 
general public was not significantly involved in the subsequent formulation of new policies. As with most such changes (see Bachrach and Baratz, 1970), it is primarily attributable to an identifiable set of individuals and groups (a policy subsystem) which, for nearly twenty years, had sought a revision of the city's laws for dealing with public drunkenness. ${ }^{6}$ Coordinated by the Washington Area Council on Alcoholism and Drug Abuse, these forces included members of city and federal criminal justice reform commissions, the news media, civil libertarian groups, public health institutions, and alcohol reform groups. This policy subsystem was instrumental in prodding Congress to enact the Alcoholic Rehabilitation Act and has continued to serve as a watchdog over the implementation of decriminalization in the District.

Although all the coalition members backed Easter and the Alcoholic Rehabilitation Act, their reasons for supporting these reforms varied, reflecting differences in professional expertise and interest. The criminal justice reform commissions and the civil libertarians stressed constitutional protections, importance of freeing the courts from "noncriminal" responsibilities, the costs of prosecuting public inebriates, and the need to concentrate limited resources on more serious crimes. The alcoholism reform groups and officials of public health institutions emphasized the provision of emergency services for the inebriate and the role of decriminalization as a stepping stone for resocializing and rehabilitating chronic inebriates. ${ }^{7}$ We found no indication that coalition members had discussed potential conflict among these goals despite the very real possibility that this may sabotage new governmental programs (Aaronson et al., 1977a, 1978; Musheno et al., 1976).

It is important to note that the Metropolitan Police Department neither volunteered, nor was asked to participate in this policy subsystem. Some members of the coalition simply assumed that the department would be opposed to decriminalization. And Jerry Wilson, then police chief, has since explained that the department was preoccupied with other matters.

The city was in a state of crisis, with street disorders occurring or threatening to occur almost weekly, with the Poor People's Campaign

6. Interview with Mary Kidd, Executive Director, Washington Area Council on Alcoholism and Drug Abuse, Washington, D.C. (July, 1974).

7. None of the members of the coalition focused on the goal of keeping the streets clear of "transient" inebriates once decriminalization was introduced. We have found that this goal is often ignored by the advocates of decriminalization but becomes a significant problem for police departments once the business community and residents begin to lodge complaints. 
absorbing much of the time of senior officials of the department, as well as diverting patrol officers to special details, and with sharp upward trends developing in serious crime and narcotics traffic. During 1968 and 1969, public inebriation was clearly a lesser priority for the police department specifically, or for the city, generally. [1975:15-16]

Subsequent reform efforts in other jurisdictions have included police departments in the formulation of policy so as to obtain accurate information about the street activity of inebriates and assure a high level of police cooperation in implementing noncriminal alternatives. $^{8}$

\section{B. Minneapolis, Minnesota}

From 1889 until 1966 Minneapolis applied Section 340.96 of the Minnesota Statutes, which makes it a criminal offense to become drunk "by voluntarily drinking intoxicating liquors." The first sign of change was the creation of the Pre-Court Screening Committee (formally entitled the Court Committee of the Task Force on Homeless Alcoholics) by Hennepin County Court Services in 1966, to review drunkenness cases and recommend disposition to the bench. ${ }^{9}$ The Committee had a membership of approximately twelve persons who represented a range of organizations most of which provided services for chronic alcoholics (e.g., Alcoholics Anonymous, the Salvation Army). The majority of drunks interviewed by the Committee were skid-row types familiar to the revolving door of criminal justice. ${ }^{10}$

But the major change occurred on May 22, 1967, with the passage of the Hospitalization and Commitment Act (Minn. Stat. Ann. §§ 253A.01-121, 1971), which provides for voluntary, involuntary, and emergency hospitalization and treatment of mentally ill and drug dependent persons, including intoxicated persons. The language governing pick-up and treatment of public inebriates ${ }^{11}$ is as follows:

8. In Kansas City, the police department played a central role in the formulation of a noncriminal alternative. In fact, a member of the department sits on the Board of Directors of the "Sober House," a detoxification and rehabilitation facility. Similarly, the St. Louis Detoxification Center was the first alternative facility sponsored by a police department.

9. Interview with Jim Pearson, Chemical Dependency Program Specialist, Hennepin County Alcohol and Inebriate Program, Minneapolis (June 9, 1975).

10. Interview with George Spano, Probation Officer, Hennepin County Municipal Court, Minneapolis (July 3, 1975).

11. The term "inebriates" does not include individuals who are merely intoxicated in public, but only chronic alcoholics: "inebriate person means any person determined as being incapable of managing himself or his affairs by reason of the habitual and excessive use of intoxicating liquors, narcotics or other drug" (\$253A.02(4)). 
A peace or health officer may take a person into custody and transport him to a licensed hospital, mental health center or other facility equipped to treat alcoholism. If the person is not endangering himself or any other person or property the peace or health officer may transport the person to his home.

Application for admission of an intoxicated person to a hospital, mental health center or other facility equipped to treat alcoholism shall be made by the peace or health officer taking such person into custody and the application shall contain a statement given by the peace or health officer stating the circumstances under which such person was taken into custody and the reasons therefor. Such person may be admitted to a facility specified in this provision for emergency care and treatment with the consent of the institution. [Hospitalization and Commitment Act § 253A.04]

Essentially, this Act provided police officers with an additional option for handling individuals intoxicated in public. No special treatment facilities for inebriates were authorized under the legislation and the health officer clause was developed to acknowledge the use of ambulance services to transport intoxicated persons.

During this transitional period, the next legal attack on the criminal processing of public inebriates came from the Minnesota courts. On April 7, 1967, Bernard Fearon was arrested for violating Minnesota Statutes § 340.96. As a defense to this charge, Fearon argued that the statute did not apply to him because he was a chronic alcoholic who, by virtue of his condition, was incapable of controlling his consumption of alcohol. The Municipal Court of Ramsey County found Fearon guilty as charged.

Fearon appealed to the Supreme Court of Minnesota, reiterating his statutory interpretation but now adding the claim that the Eighth Amendment prohibition against cruel and unusual punishment barred application of the statute to the chronic alcoholic who, as a symptom of his disease, appears intoxicated in public. On March 21, 1969, the state Supreme Court held that the statute did not apply to the chronic alcoholic (State v. Fearon, 238 Minn. 90, 166 N.W.2d 720, 1969). By so ruling, the Minnesota courts recognized that chronic alcoholism is a disease to be treated, not a criminal offense that should be punished. The court based its decision on five grounds: (1) "Voluntary drinking" under $\S 340.96$ means drinking by choice. The statute does not apply to the chronic alcoholic whose drinking is caused by his disease and therefore cannot be controlled (166 N.W.2d 720, 722-23). (2) A person cannot be convicted of committing a crime when the necessary mens rea is lacking. This would preclude conviction of the chronic alcoholic even if "voluntary" were omitted from the statute (166 N.W.2d 720, 722). (3) Although the United States 
Supreme Court upheld a drunkenness conviction under a similar Texas statute (Powell v. Texas 392 U.S. 514, 1968), it did so with serious reservations. These reservations indicate substantial doubt about the constitutionality of such statutes (166 N.W.2d 720,724). (4) The decision follows the position of most contemporary authorities regarding the treatment of chronic alcoholics (166 N.W.2d 720, 724-25). (5) The Minnesota Legislature, by adopting the Hospitalization and Commitment Act of 1967 , intended the chronic alcoholic should be considered a person in need of care, not punishment (166 N.W.2d 720, 725).

Although Fearon held that the Hospitalization and Commitment Act did supersede $\S 340.96$ in the case of chronic alcoholics, it did not invalidate local ordinances. In Minneapolis, police continued to use Chapter 37.9 of the City Ordinances to arrest intoxicated persons for disorderly conduct. Like the Easter case in Washington, the Fearon decision was viewed by municipal criminal justice officials in Hennepin County as a shift in emphasis rather than an abandonment of the criminal approach to public drunkeness.

But on March 29, 1971, the Minnesota Legislature completely eliminated the criminal processing of public drunkenness (Minn. Stats. $\S 340.961$, eff. July 1, 1971). The new provision stated that drunkenness was not a crime, and nullified any inconsistent municipal ordinance. It left law enforcement personnel with only three choices for dealing with a drunken person in a public place: (a) take the person into "custody" and transport him to a facility equipped to treat alcoholism and provide for emergency care (for a maximum of 72 hours of involuntary treatment); (b) take the person home if he is not endangering himself, others, or property; or (c) leave the person where he is found.

The legislature also committed resources for the establishment of an alternative care and treatment system. Each area mental health board throughout the state was made responsible for providing one or more detoxification centers for the custody, care, and treatment of inebriates and drug dependent persons (Minn. Stat. Ann., $\$ \S 245.68(\mathrm{~h})-(\mathrm{k})$, Supp. 1977). Hennepin County opened its first facility on the date decriminalization became effective.

On May 23, 1973, additional legislation outlined the permanent administrative structure, broadened both the services available to individuals with drinking problems and the classes of individuals who qualify as recipients, and explicitly sanctioned civilian pick-up of public drunks (Treatment for Alcohol 
and Drug Abuse Act, Minn. Stat. Ann. $\S \S 254$ A.01-.17, Supp. 1972).

In Minnesota the policy subsystem supporting decriminalization included the following forces: the traditional alcohol reform lobby (e.g., alcohol treatment groups, clergy); state commissions and associations; civic groups (e.g., the League of Women Voters); legal professionals; and mental health professionals. ${ }^{12}$ Individuals who pressed for decriminalization were often affiliated with more than one. For example, members of Alcoholics Anonymous might also be professionals in the state and county bureaucracies that service alcoholics because the state's alcoholism treatment program has permitted recovered alcoholics to be therapists and care givers ever since $1954 .^{13}$

The reformers directed their efforts at three levels of the governmental process: the courts, the state legislature, and county officials. Thus even prior to decriminalization, informal approaches to the noncriminal handling of public drunks emerged in local jurisdictions (e.g., the Hennepin County PreCourt Screening Committee). Reform activity also accounted for the smooth transition from a criminal to a treatment approach in Hennepin County. A citizen's task force with liaison to professionals was appointed by the county commissioners in anticipation of decriminalization. The task force and its professional volunteers conducted the search for the first receiving center, hired staff, and purchased all the necessary materials prior to July $1,1971 .^{14}$

Given the policy subsystem identified above, it is not surprising that the resulting legislation sought three goals: ending the jurisdiction of local courts over this problem, improving emergency services for the public inebriate, and increasing the opportunities for resocializing public inebriates. The primacy of public health concerns was assured by entrusting implementation of the decriminalization mandate to a broad-based agency dominated by public health professionals, the Department of Mental Health, Mental Retardation, and Chemical Dependency.

As in the District of Columbia, the Minneapolis Police Department was only marginally involved in deliberations con-

12. Interviews with Jim Pearson ( supra note 9) and Dale Simonson, Attorney at Law, Minneapolis (June 17, 1975).

13. Interview with Paul Thorne, Director of Hennepin County Alcoholism Receiving Center, Hennepin County Department of Mental Health, Mental Retardation, and Chemical Dependency (MH/MR/CD), Minneapolis (June 4, 1975).

14. Interview with Jim Pearson (supra note 9). 
cerning decriminalization. Thus, no member of the policy subsystem spoke for the critical community value of keeping the street clear of transient inebriates.

\section{RESEARCH DESIGN AND DATA COLLECTION}

To test the impact of decriminalization, we carried out an "interrupted time-series quasi-experiment" (Campbell and Stanley, 1963) based on a "stratified multiple-group single-I design" (Glass et al., 1975). Specifically, we collected monthly rates of arrest for public drunkenness (pre-decriminalization) and of police deliveries to detoxification facilities (postdecriminalization) for the two experimental cities: Washington, D.C., (a high arrest jurisdiction) and Minneapolis (a moderate arrest jurisdiction). ${ }^{15} \mathrm{We}$ also collected monthly arrest rates for two control cities that have not implemented decriminalization: Houston and San Francisco. ${ }^{16}$

As many scholars well know, time-series quasiexperiments often require a laborious effort to find relevant, reliable data that provide enough observations to allow sophisticated analysis. ${ }^{17}$ Since we were studying four different municipalities, we were not able to collect an equivalent number of monthly observations for each or to observe them over the same time period. Furthermore, the date of decriminalization is different in the two experimental jurisdictions.

Graphs 1 through 4 depict these differences (see the Appendix for monthly intake rates for all jurisdictions) and also indicate the placement of the intervention line for each experimental jurisdiction based on two criteria: the effective date of decriminalization in each jurisdiction, and the date that the public health facility opened to receive clients. In Minneapolis, the Alcoholism Receiving Center opened on the date decriminalization became effective-July 1, 1971. In Washington, D.C., decriminalization became effective on August 1, 1968,

15. By "high arrest jurisdiction," we mean a jurisdiction whose police department has made yearly drunkenness arrests of over 2,000 per 100,000 population (Washington had a yearly average of 5,522 per 100,000 for 1966,1967 ). By "moderate arrest jurisdiction," we mean a jurisdiction whose police department has made yearly drunkenness arrests of less than 2,000 per 100,000 population (Minneapolis had a yearly average of 1,625 per 100,000 for 1966, 1967).

16. We selected control jurisdictions that would be comparable to our experimental jurisdictions in terms of the following criteria: (1) projected change in policy (whether or not a jurisdiction was anticipating decriminalization); (2) citywide socioeconomic indicators; (3) nature of the public drunkenness problem; and (4) availability of monthly arrest data. Houston is roughly matched with Washington, D.C., and San Francisco with Minneapolis. For a full description of our site selection process see Aaronson et al. (1977b).

17. Observation requirements for sophisticated analysis are discussed in Campbell and Stanley (1963). 


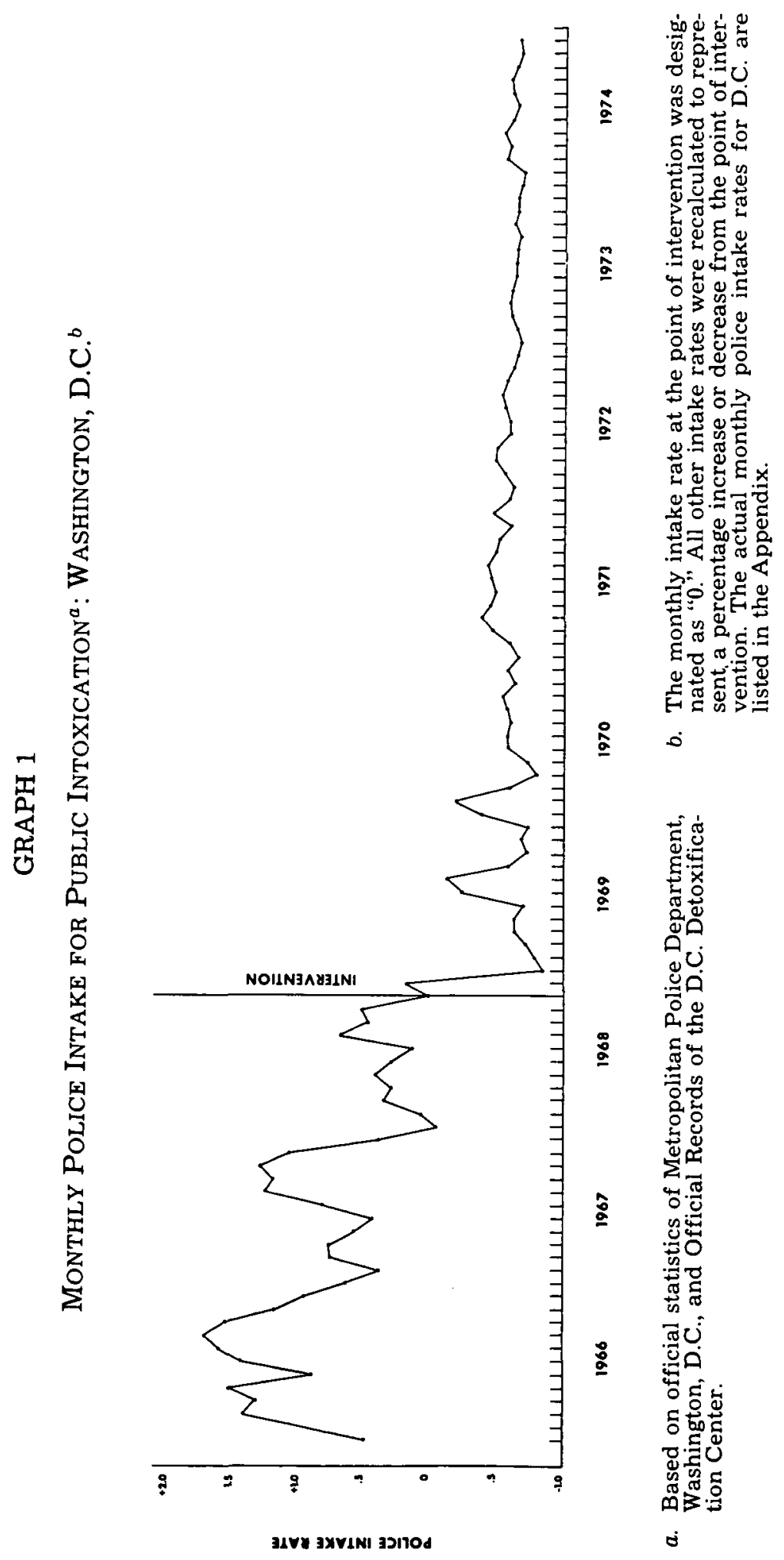



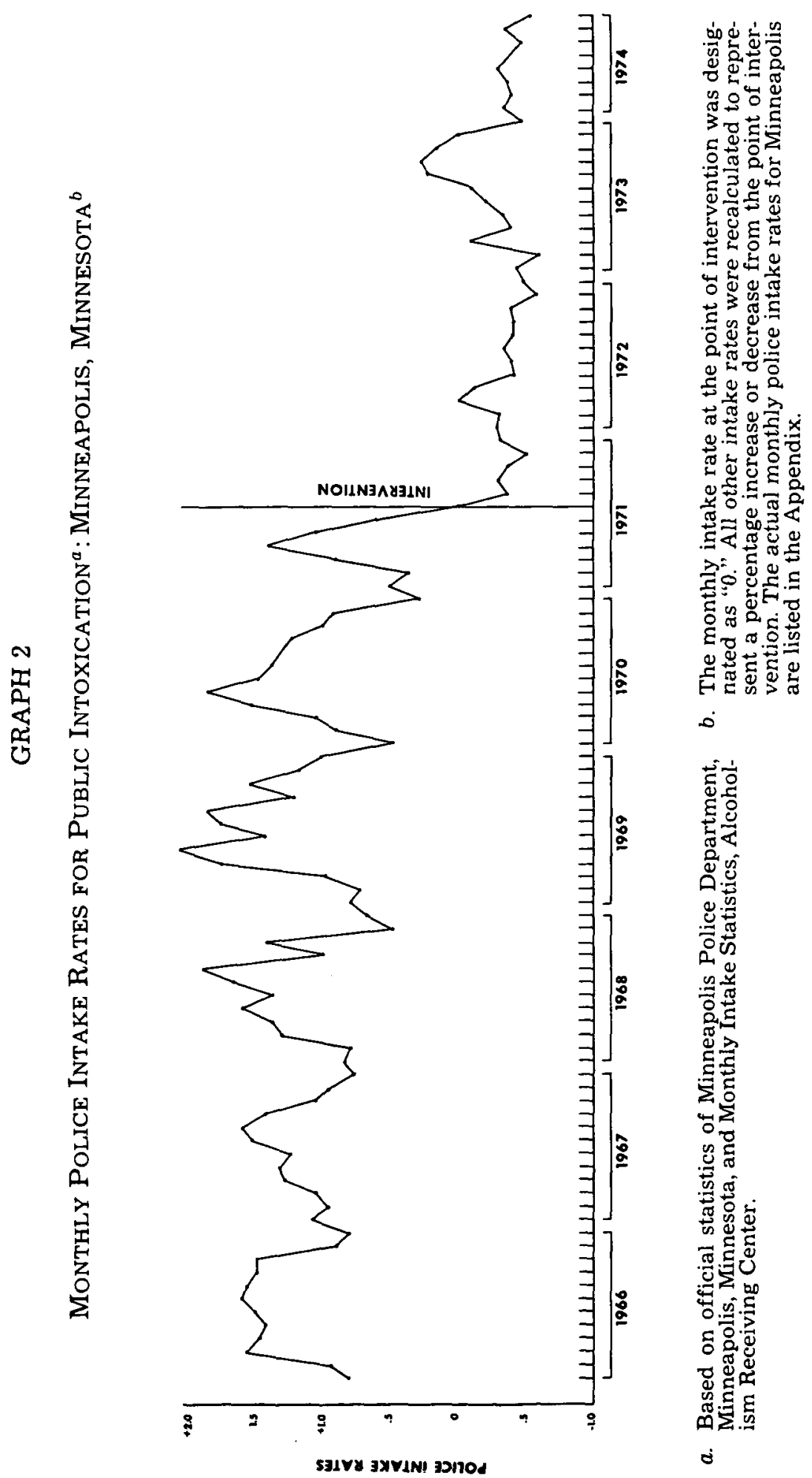


\title{
GRAPH 3
}

Monthly Police Arrests for Public Intoxication ${ }^{a}$ : Houston, TEXAS ${ }^{b}$

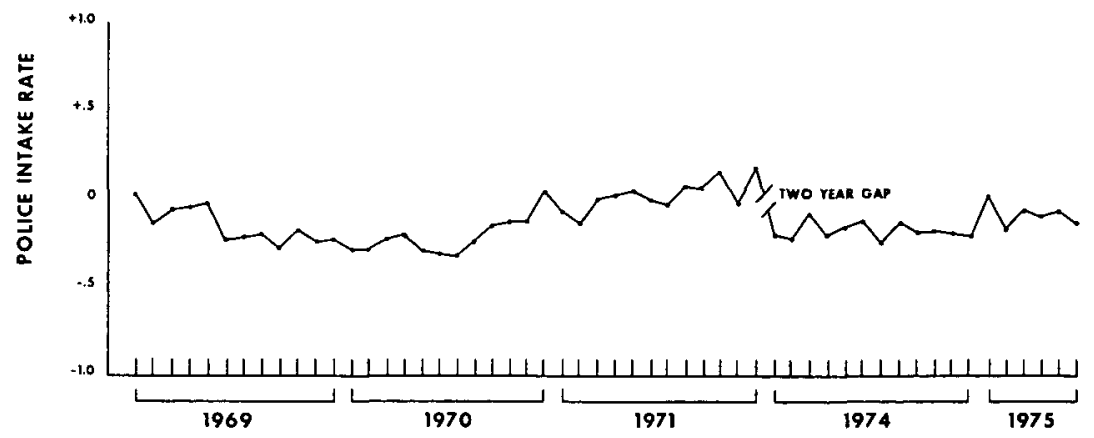

a. Based on official statistics of Houston Police Department, Houston, Texas.

$b$. The monthly arrest rate representing the midpoint of the monthly data collected was designated as " 0 ." All other monthly arrest rates were recalculated to represent a percentage increase or decrease from the midpoint. The actual monthly police arrest rates for Houston are listed in the Appendix.

\author{
GRAPH 4
}

Monthly Police Arrests for Public Intoxication ${ }^{a}$ :

San Francisco, California ${ }^{b}$

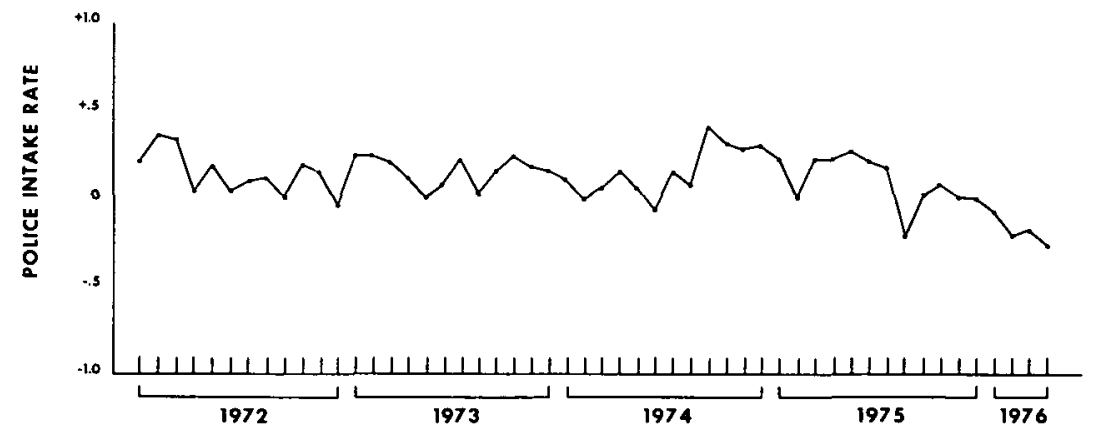

a. Based on official statistics of San Francisco Police Department, San Francisco, California.

$b$. The monthly arrest rate representing the midpoint of the monthly data collected was designated as " 0. " All other monthly arrest rates were recalculated to represent a percentage increase or decrease from the midpoint. The actual monthly police arrest rates for San Francisco are listed in the Appendix. 
but the Detoxification Center was not fully operational until November 1; we designated the latter as the point of intervention.

\section{FINDINGS}

The data provide considerable support for our decriminalization hypothesis. The intake rate in Washington, D.C., seems to fall prior to the point of intervention, apparently in response to the confusion produced by Easter (see Graph 1). According to former police chief, Jerry Wilson, "there was some concern among police immediately after the Easter decision that a police officer might become civilly liable because of the perceived requirement for determining who was an alcoholic and who was not before each arrest of an inebriate" (1975:15). However, the drop in arrests following Easter does not represent a statistically significant change in the level of intake. ${ }^{18}$ On the other hand, the computer program, CORREL, which computes autocorrelations and partial autocorrelations for raw data (see supra note 18) shows a statistically significant reduction of 764 in the estimated level of police intakes per month following decriminalization. ${ }^{19}$ In Minneapolis, where the mean monthly arrest rate under the criminal law had been much lower than in Washington (641 compared to 3152), the reduction of 263 in the estimated level of police intakes per month is even more dramatic. ${ }^{20} \mathrm{~A}$ simple visual scanning of the data from our control jurisdictions shows that no similar change occurs in police departments where criminal sanctions against public drunkenness are unaltered (see Graphs 3 and 4). ${ }^{21}$

Does this mean, then, that one effect of decriminalization is increased neglect of the public inebriate population? Rather than concluding from the above analysis that significantly more inebriates are being left on the street since decriminalization, we also investigated a series of alternative dispositions and control factors that could not be analyzed under the stratified multiple-group single-I design. The results demonstrate the

18. Fortunately, Professor Gene V. Glass of the University of Colorado has developed a computer program, CORREL, which computes autocorrelations and partial autocorrelations for raw data. CORREL also includes a seasonal option for identifying cyclic series. He applied his program to our data for Washington, D.C., and Minneapolis. The data were analyzed as $\mathrm{p}=0, \mathrm{~d}=1, \mathrm{q}=1$ (integrated moving averages) with a seasonal component (cycle=12). Using Easter as an intervention pointed for Washington, D.C., this analysis produced a $\mathrm{T}=1.05$ with 106 degrees of freedom which is not statistically significant (furthermore, the estimated intervention effect is a positive, not a negative, 337 ).

19. $\mathrm{T}=3.20$, significant at .001 with 106 degrees of freedom.

20. $T=-4.84$, significant at .001 with 102 degrees of freedom.

21. Professor Glass advised and we concurred that visual scanning of the control jurisdiction data in Graphs 3 and 4 adequately establishes that no similar effect is taking place. 
importance of "microanalysis" in tracing the impact of legal mandates on adminstrative agencies.

For each experimental jurisdiction we analyzed whether a change in the recidivism rate or in the size of the drinking population after decriminalization might explain the apparent reduction in police pick-ups.

We also examined alternative dispositions. The reform legislation in both jurisdictions allows an individual to admit himself to the detoxification facilities and grants the police two other options: to take the person home or to deliver him to a facility equipped to handle alcoholism (e.g., a hospital). The Minnesota legislation also authorizes civil pick-up of public inebriates, and the Hennepin County Alcoholism Receiving Center staffs a Civil Pick-up Van designed to reduce pressure on the Minneapolis Police Department in the downtown section of the city (First Precinct) where it is most acute. ${ }^{22}$ Finally, in addition to these approved responses, we investigated whether the police in either jurisdiction are charging public inebriates with other misdemeanors such as disorderly conduct or vagrancy.

\section{A. Washington, D.C.}

In Washington, D.C., we did not expect microanalysis to require substantial alteration in our original finding of a significant decline in the number of public inebriates formally handled by the state. Although the new legislation authorized alternative dispositions, we detected no administrative initiative on the part of public health or police personnel to implement any of these options. Indeed, our exhaustive evaluation of these alternatives revealed neither records nor other evidence that they were used extensively in the post-reform era (Aaronson et al., 1977b:116-45).

As for control factors, the size of the problem drinking population in Washington, D.C., has shown a yearly increase ever since 1960, when such estimates were first calculated by the public health community in the District. ${ }^{23}$ Thus the decline in police intake following decriminalization cannot be attributed to a decrease in public intoxication.

22. The "law on the books" in Minnesota grants broad discretionary powers to the police by including another approved option: "leave the person where he is found" (Hospitalization and Commitment Act § 253A.04).

23. Based on the Jellinek Formula for estimating alcoholism rates for populations by Dr. D. Mindlin, Director for the Adams Mill Alcoholism Center, Washington, D.C. For an explanation of the Jellinek Formula, see Jellinek, 1960. 
Our dependent variable in the foregoing research has been "rate of intake" rather than the number of different individuals picked up in each period. Perhaps the same number of different individuals is being picked up in the two periods but the rate of recidivism has declined after the reform. Although this is unlikely since decriminalization restricts involuntary commitment to 72 hours, we estimated the number of individuals the police processed in four years prior to the reform $(1964,1966,1967,1968)^{24}$ and compared these findings with the yearly recidivism rates for the D.C. Detoxification Center (1969-1973). ${ }^{25}$ As shown in Tables 1 and 2, the recidivism rates TABLE 1

ESTIMATE OF RECIDIVISM RATE FOR INDIVIDUALS Arrested by Police Prior to Reform

\begin{tabular}{cccc}
\hline Year & $\begin{array}{c}\text { Rate of }^{\text {Arrest }^{a}} \\
1964\end{array}$ & $\begin{array}{c}\text { Court Sample } \\
\text { Recidivism Rate }^{b}\end{array}$ & $\begin{array}{c}\text { Estimation of } \\
\text { Individuals Arrested }^{c}\end{array}$ \\
1966 & 44,107 & 1.58 & 27,916 \\
$1967^{d}$ & 42,189 & 2.59 & 16,289 \\
$1968^{\circ}$ & 31,860 & 1.48 & 21,527 \\
\hline
\end{tabular}

a. Based on official statistics of the Metropolitan Police Department, which are compiled on an FY basis. A rough conversion, using 50 percent of each FY has been made to render these data congruent with the court data.

b. Based on sample of arrested individuals, D.C. Court of General Sessions, by calendar year.

c. Rate of arrest divided by court sample recidivism rate.

d. Reduction from previous year is possibly attributable to police confusion over Easter and the general braking effect of this judicial mandate.

e. Reduction from previous year is due to the cessation of arrest on August 1 , the effective date of the Alcoholic Rehabilitation Act.

\section{TABLE 2}

RECIDIVISM RATE FOR INDIVIDUALS DELIVERED TO THE Detoxification CENTER, Following ReForm

\begin{tabular}{cccc}
\hline \hline Year & $\begin{array}{c}\text { Rate of } \\
\text { Admission }\end{array}$ & Recidivism & $\begin{array}{c}\text { Individuals } \\
\text { Admitted }^{a}\end{array}$ \\
\hline 1969 & 11,695 & 3.03 & 3856 \\
1970 & 14,293 & 3.32 & 4310 \\
1971 & 14,845 & 3.15 & 4707 \\
1972 & 12,465 & 2.87 & 4345 \\
1973 & 10,436 & 2.68 & 3893 \\
\hline
\end{tabular}

a. Official statistics of the D.C. Men's Detoxification Center.

24. Since police have no record of the number of individuals they processed for this charge prior to the reform, we used the index to the records of the D.C. Court of General Sessions which lists the cases for each calendar year in alphabetical order by individual name. Individuals with multiple arrests are more likely to be processed in the courts, whereas more affluent single offenders may prefer to forfeit their collateral rather than be exposed to prosecution. Therefore, we have overestimated prereform recidivism, biasing the evidence so as not to favor our research hypothesis.

25. Statistics are available for the number of individuals admitted to the Detoxification Center each year after the reform. 
are uniformly higher following the reform, and therefore the revolving door argument fails to explain the discrepancy in police intake between the two periods.

\section{GRAPH 5}

Disorderly Conduct Arrests, Reported by Metropolitan Police Department, ${ }^{a}$ Fiscal Years, 1960-1973 ${ }^{b}$

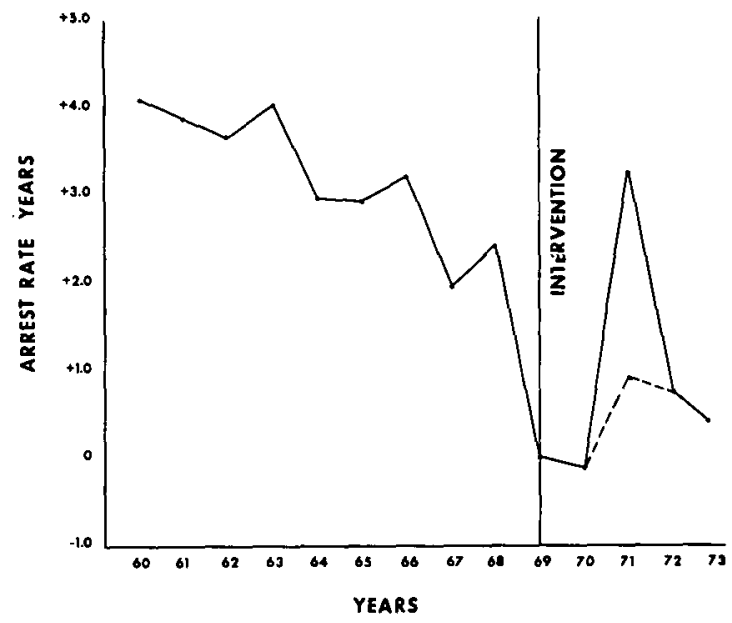

a. Figures are official statistics of Metropolitan Police Department, Washington, D.C., Annual Reports, 1960-1973. The yearly arrest rate for the first full year of decriminalization (1969) was designated as " 0 ." All other arrest rates were recalculated to represent a percentage increase or decrease from that year's rate.

b. Dotted line represents approximate arrest rate for 1971, excluding May Day demonstration arrests.

\section{GRAPH 6}

Vagrancy Arrests, Reported by Metropolitan Police DePARTMENT, ${ }^{a}$ FISCAL YEARS, 1960-1973

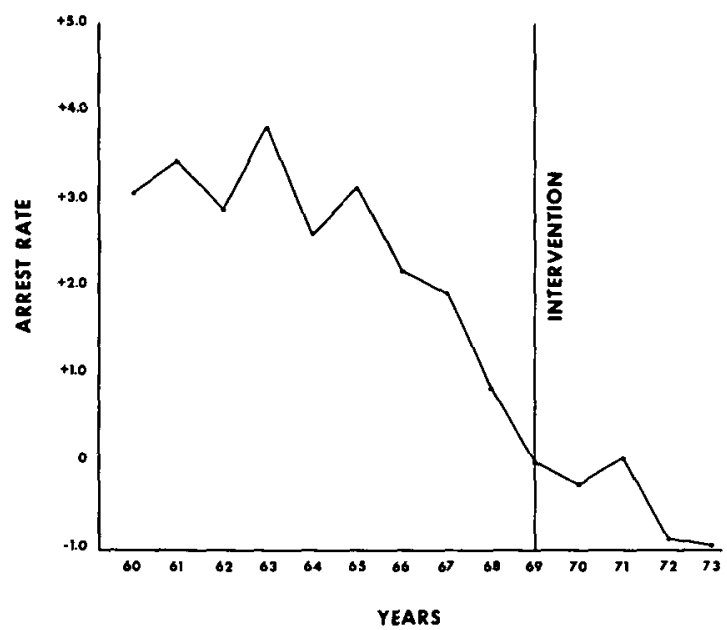

a. Figures are official statistics of Metropolitan Police Department, Washington, D.C., Annual Reports, 1960-1973. The yearly arrest rate for the first full year of decriminalization (1969) was designated as " 0 ." All other arrest rates were recalculated to represent a percentage increase or decrease from that year's rate. 
Finally, we investigated the rival hypothesis that the police and the courts have been processing public inebriates under other criminal offenses since the reform. All court personnel interviewed denied that this was the case; indeed many pointed out that removal of public drunkeness as a criminal offense was primarily responsible for reducing the case backlog in the Criminal Division of the Superior Court. Some argued that because disorderly conduct and vagrancy had previously been charged against public inebriates the reform had reduced these offenses as well.

We obtained official police statistics to probe these assertions, and found that disorderly conduct and vagrancy charges have decreased substantially in the post-reform periods (see Graphs 5 and 6). The sharp increase in disorderly conduct arrests in fiscal year 1971 (see Graph 5) is probably attributable to police actions against antiwar demonstrations, since more than 9,000 of the arrests took place during the month of the "May Day Demonstrations" in Washington, D.C., and the other, frequent antiwar demonstrations during the early 1970s could well explain the failure of the disorderly conduct arrest rate to return to the 1969-70 level. But despite the numerous arrests of demonstrators, disorderly conduct arrest levels are consistently lower after the reform than they were before it, with the single exception of the 1971 May Day inflation. The virtual disappearance of vagrancy arrests (see Graph 6) may well be due to the declining use of this offense as a result of court decisions holding such statutes unconstitutional (see, e.g., Papachriston v. City of Jacksonville, 405 U.S. 156, 1972). In any case, the data do not suggest the use of vagrancy as a substitute for the public drunkenness charge.

If the police are paying less attention to the problem of public inebriation, what criteria guide their allocation of resources, and how have these changed since the reform? We hypothesized that the decline in the number of inebriates formally processed by the police would be accompanied by an increasing emphasis on the emergency case, the skid-row drunk, for whom some action is required and no adequate alternative is readily available.

Washington, D.C., is the only jurisdiction in which we were able to investigate the "qualitative impact" of decriminalization by studying existing reports on the public inebriate population and collecting original data on the characteristics of those processed for public intoxication before and after the reform. The Committee on Prisons, Probation and Parole found that 
58.2 percent of the individuals picked up for public intoxication in the District of Columbia during 1956 either forfeited their collateral, were fined or were released (1957:89). The Committee contrasted these "social drinkers" with 41.8 percent of inebriates committed to the Workhouse, whom it divided into three categories.

Many are relatively youthful offenders who are simply intoxicated at the time of arrest; a somewhat larger group are problem drinkers, bordering on chronic alcoholism-but who have families, job prospects, and a desire to get back home and back to work; finally, the great majority of the approximately 14,000 intoxicants committed each year to the Workhouse are chronic skid-row alcoholics. [1957:103]

The report thus indicates that the police picked up a range of public inebriates and did not concentrate solely on the chronic skid-row inebriate. On the other hand, a study of those entering the Alcoholic Detoxification Center after the reform reveals a more homogenous population.

The composite picture is that of a black man, not married, who tends to be in his mid-forties, having completed ten years of education, of low socio-economic status. ... He has an average of 18 prior admissions to the Alcoholic Detoxification Center. [Research and Statistics Division, $1974]^{26}$

We then drew random samples of individuals arrested by the police during two years prior to the reform $(1963-1967)^{27}$

TABLE 3

\section{Background Characteristics of Persons Arrested by Police and Admitted to Detoxification Center}

\begin{tabular}{lcc}
\hline & $\begin{array}{c}\text { Persons Arrested } \\
\text { by Police prior } \\
\text { to Reform }\end{array}$ & $\begin{array}{c}\text { Persons Admitted } \\
\text { to Detoxification } \\
\text { Center after Reform }\end{array}$ \\
\hline Mean Age & 43 & 44.4 \\
Race & $51 \%$ & $60.8 \%$ \\
$\quad$ Black & & $37.8 \%$ \\
White & & $1.4 \%$ \\
$\quad \begin{array}{l}\text { Other } \\
\text { No occupation, }\end{array}$ & $64.1 \%$ & $64.9 \%$ \\
unskilled, or \\
semiskilled \\
$\quad$ & \\
Marital status & & \\
Married & & $17.9 \%$ \\
Divorced or & $38.8 \%$ & $60.0 \%$ \\
$\quad$ separated & $9.0 \%$ & \\
& $(\mathrm{~N}$ varies between & \\
\hline
\end{tabular}

a. Major shifts in separation and divorce rates have occurred throughout society, which may partly explain this difference.

26. These 18 admissions represent a lifetime experience for 500 public inebriates and should not be confused with the annual recidivism rates reported in Table 2.

27. Police arrest records are generally filled with inaccuracies because officers rely on the integrity of the arrested individual for background information. Nevertheless, these are the only available source for these data. 
and of those admitted to the Detoxification Center during five subsequent years (1969-73), comparing their backgrounds in terms of indicators often associated with skid-row inebriates: low socioeconomic status and undersocialization (Straus, 1974) (we were unable to measure the third indicator, institutional dependency). There are few significant differences in most background variables between these two periods, with the exception of marital status. The composite picture of the public inebriate admitted to the Detoxification Center is a black male in his mid-forties, single or separated, with little education and low occupational skills, who resides in those parts of the city with the highest level of health problems. ${ }^{28}$

These traits characterize the skid-row public inebriate. Others rarely find their way into the Detoxification Center. Indeed former Police Chief Jerry Wilson believed that one purpose of the Alcoholic Rehabilitation Act was to create an alternative means for servicing skid-row inebriates:

Of course, the language of the ARA avoids saying directly that it is the homeless, derelict inebriate who is to be taken to the Detoxification Center for treatment. But when you think of the discussions that led up to the ARA and to its actual language, you can construct an argument that the underlying intent is that the Detoxification Center will deal primarily with the derelict. For example, there is the provision for taking or sending the intoxicated individual home as an alternative to the Detoxification Center. Clearly, this is intended and functions to excuse most persons who have homes from what really amounts to an arrest and incarceration. In practice, of course, the police rarely take inebriates home, but instead send them home by putting them in taxicabs or turning them over to friends or else indirectly send them home simply by letting them go on their way so long as they are not staggering through traffic. [1975:19]

Despite the limitations of our datä, it appears one consequence of decriminalization has been to focus the energies of the police' upon skid-row alcoholics, to the neglect of other public inebriates. This is disturbing for two reasons. First, it frustrates the primary goal of the reform-rehabilitation and resocialization. These policies are least likely to succeed with the skid-row alcoholic, who is being admitted to the Detoxification Center, and most likely to succeed with those who are being overlooked by the police. Second, it increases, rather than

28. We plotted the addresses of those admitted to the Center in terms of the service areas of the Department of Human Resources. The service area with the highest rate of socioeconomic health related problems (the Model Cities Area, which also contains the Center) was the residence of 29.1 percent of admittees; 63.7 percent of admittees reside in the three most deprived service areas. 
reduces, the violation of constitutional principles by depriving skid-row alcoholics of equal protection of law.

\section{B. Minneapolis}

As in the District of Columbia, neither of the control factors explains the discrepancy in intake between the two periods. The problem drinking population has slightly increased since decriminalization ${ }^{29}$ and public drunkenness recidivism rates are substantially higher (see Table 4).

\section{TABLE 4}

Comparison of Public Drunkenness Recidivism Rates under the CRiminal Law and since Decriminalization

\begin{tabular}{ccccc}
\hline \hline Year & $\begin{array}{c}\text { Rate of } \\
\text { Arrest/ } \\
\text { Admission }\end{array}$ & $\begin{array}{c}\text { Number of } \\
\text { Individuals }\end{array}$ & $\begin{array}{c}\text { Estimated } \\
\text { Recidivism }\end{array}$ & $\begin{array}{c}\text { Estimation of } \\
\text { Individuals }\end{array}$ \\
\hline $1967^{a}$ & 7670 & 145 & 3.79 & 2024 \\
$1970^{a}$ & 7394 & 176 & 3.94 & 1877 \\
$1972^{b}$ & 2270 & 176 & 4.71 & 482 \\
$1974^{b}$ & 2094 & 151 & 5.03 & 416 \\
\hline
\end{tabular}

a. Based on Official Arrest Records, Minneapolis Police Department, Bureau of Identifications.

b. Based on Official Records, Alcoholism Receiving Center, Department of $\mathrm{MH} / \mathrm{MR} / \mathrm{CD}$.

c. Rate of arrest divided by recidivism rate.

Although we found little incidence of home deliveries or use of other health facilities by the Minneapolis Police (Aaronson et al., 1977b:248-53), our investigation of alternative dispositions by the Alcoholism Receiving Center (ARC) did produce significant findings. Unlike most treatment programs which rely almost totally on police departments for their intake, ARC's staff has aggressively sought to attract clients. ${ }^{30}$ The development of the Civil Pick-up Service was designed to reduce pressure on the Minneapolis Police Department in the downtown section of the city (First Precinct) where street inebriate problems are most acute (Boche, 1975). And the ARC has encouraged problem drinkers from more stable socioeconomic

29. Robert Olander, Research Sociologist for the Department of Mental Health, Mental Retardation, and Chemical Dependency, applied the standard Jellinek formula to the mean adult population in Hennepin County for the two periods $1965-70$ and 1971-75, drawn from the yearly census, and arrived at estimates of potential problem drinkers of 37,346 and 38,390 . This finding is strengthened by the fact that Hennepin County registered a slight decrease in population between 1971 and 1975.

30. Interview with Leonard Boche, Director, Department of $\mathrm{MH} / \mathrm{MR} / \mathrm{CD}, \mathrm{Min}$ neapolis, (June 3, 1975). 
backgrounds to admit themselves, using advertising and working closely with business and with government agencies. ${ }^{31} \mathrm{We}$ therefore speculated that such a high involvement by the public health community might compensate for the reduction in police attention to this problem.

Graph 7 shows that this is in fact what occurred. ${ }^{32}$ Before

\section{GRAPH 7}

Public Drunkenness Arrests, ${ }^{a}$ Police Intakes (P), ${ }^{b}$ And All Nonpolice Referrals (R) to Alcoholism Receiving

Center, ${ }^{c}$ YeARS $1960-1975$

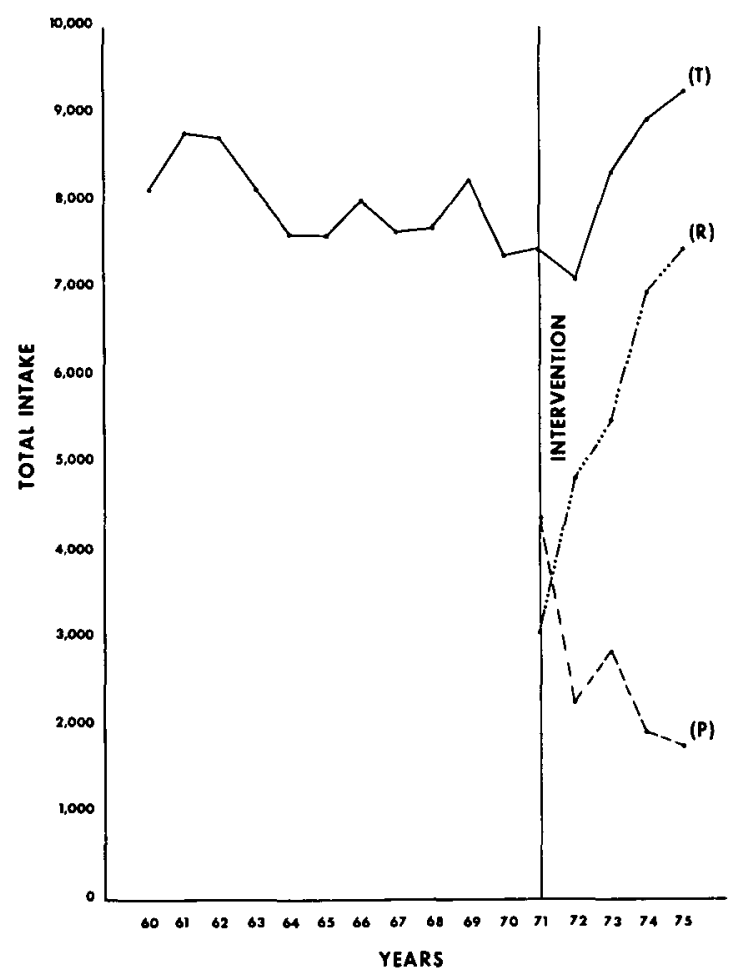

a. Figures are total drunkenness arrests, official statistics of the Minneapolis Police Department, Annual Reports, 1960-1975.

b. Figures are all police deliveries, comparison statistics, Alcoholism Receiving Center, 1971-1975.

c. Figures are civil pick-ups, self-admissions, and other means of nonpolice intake combined, comparison statistics, Alcoholism Receiving Center, 1971-1975.

31. Interview with Paul Thorne, Director, Alcoholism Receiving Center, Minneapolis (June 5, 1975).

32. Only yearly data are available: $\mathrm{T}=.16, \mathrm{df}=11+5-2=14, \mathrm{p}=\mathrm{N}$.S. Thus, there is no significant difference in pick-ups between the two periods when one adds the intake generated by the efforts of the Alcoholism Receiving Center staff. 
the initiation of the Civilian Pick-up service "the Minneapolis Police Department accounted for $40 \%$ of the total admissions and $60 \%$ of admissions from 4:00 P.M. to 12:00 P.M." (Boche, 1975:1). Thereafter "the Pick-up Team transported almost 50\% of the total admissions to the Center and $80 \%$ of police and team admissions combined" for the same hours (Boche, 1975:2). Statistics collected by ARC show that the Civilian Pick-up Service has actually increased total admissions while further reducing police involvement. For example, in June through August of 1974 "the total number of admissions to the Center increased $17 \%$ (from 2299 to 2689) while police referrals were reduced to 480 admissions" (Boche, 1975:4). During the first eight months of 1974, Civilian Pick-up admissions increased from 19 percent of total admissions to 27 percent while police admissions were reduced from 23 to 17 percent (Boche, 1975:4).

It should be stressed, however, that persons who admit themselves to the ARC (approximately half of the total admissions during this period) may be a different population from the typical skid-row inebriate. To the extent that this is so, we have not yet fully accounted for the inebriate population previously handled by the police. Perhaps the police have diverted their energies to controlling public inebriates with minor criminal charges. Indeed, public health officials suggested that subsequent to decriminalization the police were arresting a considerable number of public inebriates for disorderly conduct and relasing them before a court appearance was required. ${ }^{33}$

We obtained official police statistics on disorderly conduct and vagrancy. The findings displayed in Graphs 8 and 9 strongly indicate that the police are arresting public inebriates for disorderly conduct. Although vagrancy arrests have shown a steady decline since 1960 , disorderly conduct arrests have significantly increased since decriminalization. ${ }^{34}$ From 1960 to 1966 , the yearly average for disorderly conduct arrests was 697 ; during the transitional period following the introduction of precourt screening (1967-70) this average increased to 1167; since decriminalization. (1971-75) it has jumped to 1875. Thus, in order to keep the streets clear of skid-row inebriates, and because of overcrowding at the Alcoholism Receiving Center, the police have come to rely on disorderly conduct arrests as a means of control.

33. Interview with Leonard Boche (supra note 30).

34. Monthly disorderly conduct arrest data were collected. The estimated intervention effect is +72.62 police arrests $(T=6.61$, degrees of freedom $=$ 34). 


\section{GRAPH 8}

Disorderly Arrests, Reported by the Minneapolis Police Department ${ }^{a}$ Fiscal Years, $1960-1975$

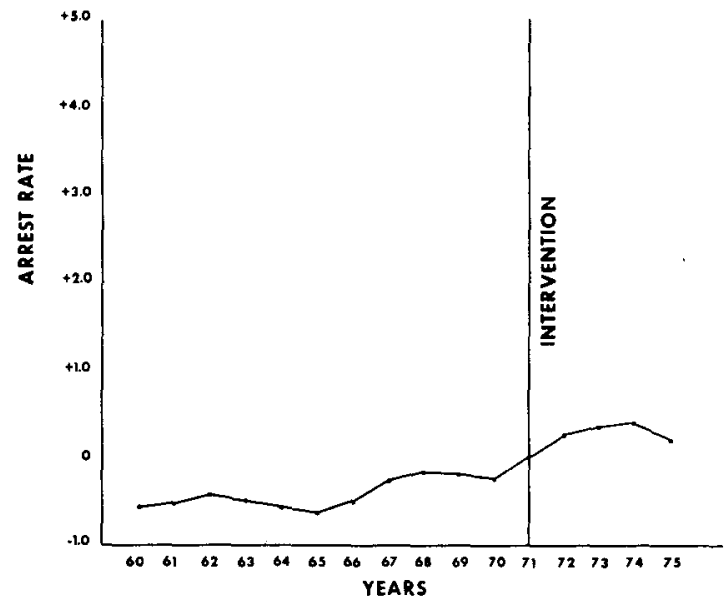

a. Figures are yearly statistics, official statistics of the Minneapolis Police Department, Annual Reports, 1960-1975. The yearly arrest rate for the year of decriminalization (1971) was designated as "0." All other arrest rates were recalculated to represent a percentage increase or decrease from that year's rate.

\section{GRAPH 9}

Vagrancy Arrests, Reported by the Minneapolis Police Department ${ }^{a}$ Fiscal Years, 1963-1975

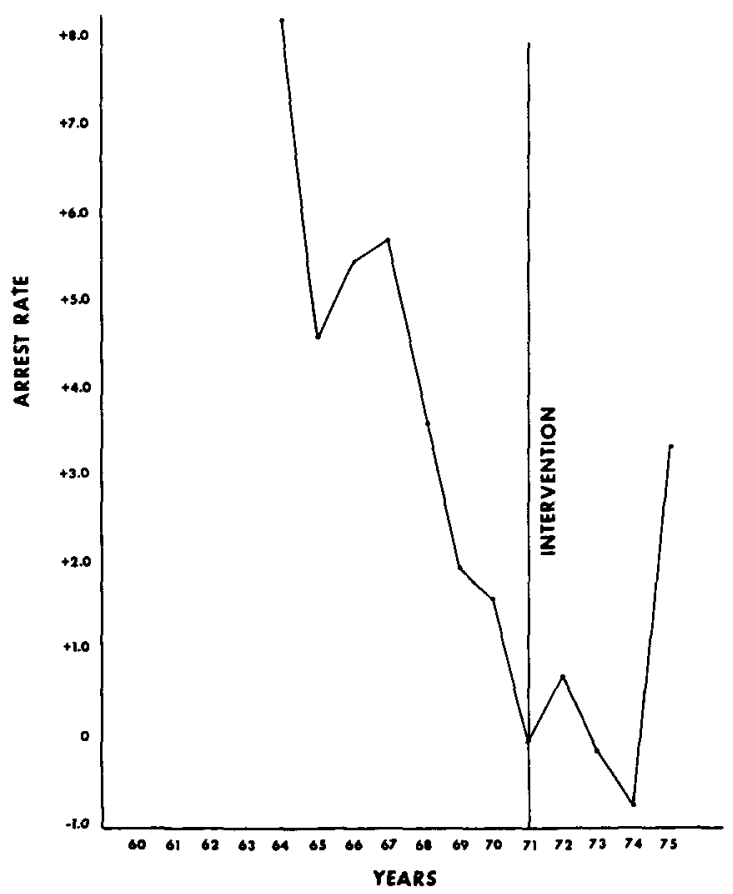

a. Figures are yearly statistics, official statistics of the Minneapolis Police Department, Annual Reports, 1963-1975. The yearly arrest rate for the year of decriminalization (1971) was designated as " 0 ." All other arrest rates were recalculated to represent a percentage increase or decrease from that year's rate. 


\section{v. CONCLUSION}

Our multiple time-series analysis does confirm a statistically significant decline in the number of public inebriates formally handled by the police in the manner designated by the "law in the books." This finding raises serious doubts about the use of police to implement noncriminal regulations and lends considerable support to our proposition that decriminalization introduces a mass of disincentives to formally approved police intervention. However, our comparative analysis does not lead to the conclusion that more inebriates necessarily will be left on the street after decriminalization. As revealed in our microanalyses of the experimental jurisdictions, proactive behavior by the public health community (e.g., the use of a civilian intake van and the encouragement of self-admissions) does compensate for reduced police attention in Minneapolis.

Certain environmental differences between the two cities may partially account for the disparity in pickup practices. Until the late 1960 s, the Minneapolis Police Department and community leaders tolerated the existence of "safe zones" where skid-row inebriates could freely congregate and reside unnoticed by most citizens. A small "hobo haven" was located on property owned by the Great Northern Railroad, but the greatest number of transient drinkers lived on Nicollet Island, situated in the Mississippi River where it passes through Minneapolis. Over the years this area evolved into an unofficial shanty town for transients, with flophouses, shacks, and even liquor stores. Although a few old houses still stand, the city has now virtually leveled the island and is redeveloping it as an outdoor art and recreation area. This drove the inebriate population into the thriving downtown commercial and business district, which was revitalized in the early 1970s. Strong business protests as well as increased numbers of complaints have placed the police under heavy pressure to keep the streets clear of inebriates who offend shoppers. ${ }^{35}$ This probably explains the police department's use of disorderly conduct charges to detain public inebriates overnight when the detoxification facility is full or is unwilling to handle some of the more troublesome transients.

In the District of Columbia, the Metropolitan Police Department can rely on more informal mechanisms to keep public inebriates out of the downtown tourist and business district. This important commercial area is part of a larger subdivision

35. Interview with Paul Thorne (supra note 31). 
of Washington that contains many pockets of extreme poverty characterized by abandoned buildings and vacant lots (Aaronson et al., 1977b:112-13). These blighted area neighborhoods are within easy walking distance of the major commercial district. At present they are "safe zones" for public inebriates and police use such informal tactics as "moving transients along" in order to keep them away from commercially important thoroughfares. Direct observation by our research teams, as well as interviews with police and public health officials in the city, confirm the conclusion that public inebriates are permitted to congregage in these areas (Aaronson et al., 1977b:141).

Differences in the availability of public health resources for inebriates may also help to account for the higher intake rate in Minneapolis. Public health officials in both communities have been outspoken about the limited bed space in their facilities. But in 1974, Minneapolis opened a second facility, Southside Detox, principally serving the Native American population in the Model Cities area. ${ }^{36}$ And Hennepin County public health officials have recently drawn up plans for a series of "satellite facilities" to decentralize services to the public inebriate population. In Washington by contrast, public health officials have obtained no increase in resources since the initial funding of the Detoxification Center.

Finally, decriminalization provided the police command in Washington with an opportunity to shift priorities at a time when the department was under heavy pressure to handle massive demonstrations and fight street crime. The Minneapolis Police Department experienced no such competing demands for its services. On the contrary, urban renewal coupled with the loss of the criminal sanction for public drunkenness placed increased pressures on the Minneapolis force to remove inebriates from the streets. Neither the proponents of decriminalization nor the police fully anticipated these historically specific factors. ${ }^{37}$

36. Interview with Marvin Mannypenny, Director, Southside Detox, Minneapolis (July 7, 1975).

37. In this paper we have not attempted to develop alternative solutions to the problems created by decriminalization. However, we have written a prescriptive paper on this subject, see Aaronson et al. (1977a, 1978). 


\begin{tabular}{|c|c|c|c|c|}
\hline & & PPENDIX & & \\
\hline & ONTHLY POLICE I & TAKE RATES & OR All Cities & \\
\hline 1966 & Washington, D.C. & Minneapolis & San Francisco & Houston \\
\hline January & 2581 & 529 & & \\
\hline February & 3352 & 567 & & \\
\hline March & 4156 & 747 & & \\
\hline April & 3994 & 719 & & \\
\hline May & 4391 & 707 & & \\
\hline June & 3274 & 728 & & \\
\hline July & 4628 & 758 & & \\
\hline August & 4502 & 746 & & \\
\hline September & 4705 & 725 & & \\
\hline October & 4438 & 725 & & \\
\hline November & 3737 & 555 & & \\
\hline December & 3382 & 526 & & \\
\hline 1967 & & & & \\
\hline January & 2845 & 612 & & \\
\hline February & 2368 & 570 & & \\
\hline March & 3039 & 597 & & \\
\hline April & 3055 & 666 & & \\
\hline May & 2698 & 677 & & \\
\hline June & 2481 & 651 & & \\
\hline July & 3133 & 736 & & \\
\hline August & 3896 & 757 & & \\
\hline September & 3778 & 708 & & \\
\hline October & 3968 & 601 & & \\
\hline November & 3566 & 569 & & \\
\hline December & 2412 & 526 & & \\
\hline 1968 & & & & \\
\hline January & 1635 & 538 & & \\
\hline February & 1840 & 525 & & \\
\hline March & 2347 & 668 & & \\
\hline April & 2228 & 692 & & \\
\hline May & 2457 & 762 & & \\
\hline June & 2245 & 693 & & \\
\hline July & 1966 & 775 & & \\
\hline August & 2915 & 843 & & \\
\hline September & 2537 & 578 & & \\
\hline October & 2631 & 708 & & \\
\hline November & 1794 & 434 & & \\
\hline December & 2049 & 489 & & \\
\hline 1969 & & & & \\
\hline January & 254 & 528 & & 2639 \\
\hline February & 367 & 505 & & 2225 \\
\hline March & 481 & 576 & & 2435 \\
\hline April & 621 & 805 & & 2445 \\
\hline May & 613 & 895 & & 2489 \\
\hline June & 489 & 707 & & 1974 \\
\hline July & 1313 & 803 & & 2021 \\
\hline August & 1520 & 834 & & 2062 \\
\hline September & 703 & 645 & & 1887 \\
\hline October & 465 & 745 & & 2138 \\
\hline November & 526 & 637 & & 1961 \\
\hline December & 445 & 588 & & 1994 \\
\hline
\end{tabular}


1970

Washington, D.C. Minneapolis San Francisco Houston

January

February

March

April

May

June

July

August

September

October

November

December

1971

January

February

March

April

May

June

July

August

September

October

November

December

1086

1972

January

February

March

April

May

June

July

August

September

October

November

December

1973

January

February

March

April

May

June

July

August

September

October

November

December
1411

721

343

460

714

738

675

747

785

650

730

603

704

920

1080

942

873

941

975

868

835

690

916

429

552

598

735

831

720

691

670

649

586

559

374

442

396

555

707

616

473

289

183

204

183

140

201

710

670

776

896

880

719

724

776

810

748

660

622

587

613

682

719

688

626

639

612

574

644

588

596
1857

1848

1971

2025

1815

1780

1741

1948

2185

2248

2248

2730

2386

2209

2592

2665

2709

2582

2497

2809

2859

2996

2505

3072

$\begin{array}{ll}203 & 1213 \\ 201 & 1431 \\ 290 & 1417 \\ 256 & 1095 \\ 169 & 1254 \\ 174 & 1091 \\ 192 & 1162 \\ 170 & 1182 \\ 169 & 1065 \\ 170 & 1253 \\ 124 & 1209 \\ 152 & 1008\end{array}$

$163 \quad 1306$

$114 \quad 1306$

$208 \quad 1272$

$176 \quad 1185$

$191 \quad 1060$

$230 \quad 1134$

$258 \quad 1284$

$356 \quad 1083$

$375 \quad 1208$

$339 \quad 1312$

$291 \quad 1246$

$150 \quad 1222$ 


\section{Monthly Police Intake Rates for All Cities}

1974

Washington, D.C. Minneapolis San Francisco Houston

2062

January

February

$\mathbf{5 5 7}$
543
745
692
773
659
604
661
668
621
562
580

191
175
183
208
182
154
193
133

March

April

May

June

July

August

September

October

November

December

580

1167

1030

1123

1116

1225

1975

January

February

March

April

May

June

July

August

September

October

November

Decernber

1976

January

February

March

April
573

578

651

729

585

707

581

576

641

592

446

542
1228

972

1141

1480

1389

1348

1367

2009

2342

2034

2152

2244

1933

2239

2075

2107

2079

2038

$1294 \quad 2633$

$1050 \quad 2136$

$1294 \quad 2383$

$1249 \quad 2320$

$1339 \quad 2387$

$1281 \quad 2211$

1232

801

1074

1136

1348

1367

973

820

852

774

\section{REFERENCES}

AARONSON, David E., C. Thomas DIENES and Michael C. MUSHENO (1977a) "Police Discretion: Rationality in Handling Public Inebriates, Part I," 29 Administrative Law Review 447.

(1977b) The Impact of Decriminalization on the Intake Process for Public Inebriates: A Final Report. Washington, D.C.: NILE-LEAA.

(1978) "Police Discretion Rationality in Handling Public Inebriates, Part II," 29 Administrative Law Review 93.

AARONSON, David E., D. HOFF, P. JASZI, N. KITTRIE and D. SAARI (1977c) The New Justice: Alternatives to Conventional Adjudication. Washington, D.C.: U.S.G.P.O.

AARONSON, David E. and J. SWEENEY (1975) "Criminal Law Reform in the District of Columbia: An Assessment of Needs and Directions," 24 American University Law Review 207.

BACHRACH, Peter and Morton BARATZ (1970) Power and Poverty: Theory and Practice. New York: Oxford University Press.

BITTNER, Egon (1967) "The Police on Skid Row: A Study of Peacekeeping," 32 American Sociological Review 699.

BOCHE, Leonard (1975) "The Public Inebriate: An Innovative Approach to the Transporting of Clients to a Detoxification Center." Presented at the North American Congress on Alcohol and Drug Problems, Seattle, Washington. 
CAMPBELL, Donald and H. Laurence ROSS (1968) "The Connecticut Crackdown on Speeding," 3 Law \& Society Review 33.

CAMPBELL, Donald T. and Julian C. STANLEY (1963) Experimental and Quasi-Experimental Designs for Research. Chicago: Rand McNally.

COMMITEE ON PRISONS PROBATION AND PAROLE (1957) Karrick Report. Washington, D.C.: U.S.G.P.O.

DAVIS, Kenneth Culp (1975) Police Discretion. St. Paul, Minn.: West Publishing Co.

DOLBEARE, Kenneth (1967) Trial Courts in Urban Politics. New York: John Wiley \& Sons.

DYE, Thomas (1972) Understanding Public Policy. Englewood Cliffs, N.J.: Prentice-Hall

FREEMAN, J. Leiper (1965) The Political Process. New York: Random House.

FRITSCHLER, A. Lee (1969) Smoking and Politics: Policymaking and the Federal Bureaucracy. New York: Appleton-Century-Crofts.

GAMMAGE, Allen Z. et al., (1972) Alcoholism, Skid Row, and the Police. Springfield, Ill.: Thomas.

GLASS, Gene (1968) "Analysis of Data on the Connecticut Speeding Crackdown as a Time-Series Quasi-Experiment," 3 Law \& Society Review 55.

GLASS, Gene, George TIAO, and Thomas MAQUIRE (1971) "The 1960 Revision of German Divorce Laws: Analysis of Data as a Time-Series Quasi-Experiment," 5 Law \& Society Review 539.

GLASS, Gene V., Victor WILLSON and John GOTTMAN (1975) Design and Analysis of Time-Series Experiments. Boulder: Colorado Associated University Press.

GOLDSTEIN, Joseph (1960) "Police Discretion Not To Invoke the Criminal Process: Low-Visibility Decisions in the Administration of Justice," 69 Yale Law Journal 171.

GRAD, Frank, A. GOLDBERG and B. SHAPIRO (1971) Alcoholism and the Law. Dobbs Ferry, N.Y.: Oceana Publications.

JELLINEK, Elvin (1960) The Disease Concept of Alcoholism. New Haven, Conn.: College and University Press.

KITTRIE, Nicholas (1971) The Right To Be Different. Baltimore: The Johns Hopkins Press.

LaFAVE, Wayne (1965) Arrest: The Decision To Take a Suspect into Custody. Boston: Little, Brown.

MEDALIE, Richard, Leonard ZEITZ and Paul ALEXANDER (1968) "Custodial Police Interrogation in our Nation's Capital: An Attempt to Implement Miranda," 66 Michigan Law Review 1347.

METROPOLITAN POLICE DEPARTMENT (1968), Memorandum Orders Nos. 8 and 11, Series 1968, Washington, D.C.

MLNER, Neal (1970) "Comparative Analysis of Patterns of Compliance with Supreme Court Decisions: Miranda and the Police in Four Communities," 5 Law \& Society Review 119.

MORRIS, Norval and Gordon HAWKINS (1969) The Honest Politician's Guide to Crime Control. Chicago: University of Chicago Press.

MUSHENO, Michael C., Dennis PALUMBO and James LEVINE (1976) "Evaluating Alternatives in Criminal Justice: A Policy Impact Model," 22 Crime and Delinquency 265.

NATIONAL CONFERENCE OF COMMISSIONERS ON UNIFORM STATE LAWS (1971) Uniform Alcoholism and Intoxication Treatment Act, in Dept. of H.E.W., First Special Report to the U.S. Congress on Alcohol and Health. Washington, D.C.: Department of H.E.W.

NIMMER, Raymond (1971) Two Million Unnecessary Arrests. Chicago: American Bar Association.

OSTROM, Elinor (1973) Community Organization and the Provision of Police Services. Beverly Hills, Calif.: Sage Publications.

PACKER, Herbert (1968) The Limits of the Criminal Sanction. Stanford: Stanford University Press.

PITTMAN, D. and W. GORDON (1967) Revolving Door: A Study of the Chronic Police Case Inebriate. Glencoe, Ill.: Free Press. 
RESEARCH AND STATISTICS DIVISION, OFFICE OF PLANNING AND STATE AGENCY AFFAIRS (1974) Follow-Up Study of Five Hundred Public Inebriates. Washington, D.C.: Department of Human Resources.

ROSS, H. Laurence (1975) "The Scandinavian Myth: The Effectiveness of Drinking-and-Driving Legislation in Sweden and Norway," 4 Journal of Legal Studies 258.

RUBINGTON, Earl (1970) "Post Treatment Contacts and Lengths of Stay in a Halfway House," 31 Quarterly Journal of Studies on Alcohol 167.

SCHUR, Edwin (1965) Crimes without Victims. Englewood Cliffs, N.J.: Prentice-Hall.

SCHUR, Edwin and Hugo BEDAU (1974) Victimless Crimes: Two Sides of a Controversy. Englewood Cliffs, N.J.: Prentice-Hall.

SKOLNICK, Jerome (1967) Justice without Trial. New York: John Wiley \& Sons.

STRAUS, Robert (1974) Escape from Custody. New York: Harper \& Row.

TTTUS, H.W. (1973) "Perils of Decriminalization." Presented at the Second Criminal Justice Conference, University of Oregon.

U.S. DEPARTMENT OF H.E.W. (1971) First Special Report to the U.S. Congress on Alcohol and Health. Washington, D.C.: U.S.G.P.O.

WILSON, James Q. (1968) Varieties of Police Behavior. Cambridge, Mass.: Harvard University Press.

WILSON, Jerry V. (1975) "Police Discretion and the Public Inebriate." Presented to Faculty of Washington College of Law, the American University.

ZIMRING, Franklin (1975) "Firearms and Federal Law: The Gun Control Act of 1968," 4 Journal of Legal Studies 133. 